\title{
Performance of juveniles of Pseudoplatystoma fasciatum fed graded levels of corn gluten meal
}

\author{
Álvaro José de Almeida Bicudo(1), Ricardo Borghesi(2), Jony Koji Dairiki(3), Ricardo Yuji Sado(4) \\ and José Eurico Possebon Cyrino(5)
}

\begin{abstract}
(1) Universidade Federal Rural de Pernambuco, Unidade Acadêmica de Garanhuns, Avenida Bom Pastor, s/no, CEP 55296-901 Garanhuns, PE, Brazil. E-mail: alvaro.bicudo@uag.ufrpe.br (2)Embrapa Pantanal, Rua 21 de Setembro, no 1.880, Caixa Postal 109, CEP 79320-900 Corumbá, MS, Brazil. E-mail: borghesi@cpap.embrapa.br ${ }^{(3)}$ Embrapa Amazônia Ocidental, Rodovia AM-010, Km 29, Caixa Postal 319, CEP 69010-970 Manaus, AM, Brazil. E-mail: jony.dairiki@cpaa.embrapa.br (4)Universidade Tecnológica Federal do Paraná, Campus Dois Vizinhos, Coordenação de Zootecnia, Estrada para Boa Esperança, Km 04, CEP 85660-000 Dois Vizinhos, PR, Brazil. E-mail: ricardoysado@utfpr.edu.br (5)Universidade de São Paulo, Escola Superior de Agricultura Luiz de Queiroz, Departamento de Zootecnia, Avenida Pádua Dias, № 11, CEP 13418-900 Piracicaba, SP, Brazil. E-mail: jepcyrin@esalq.usp.br
\end{abstract}

Abstract - The objective of this work was to evaluate corn gluten meal (CGM) as a substitute for fish meal in diets for striped catfish (Pseudoplatystoma fasciatum) juveniles. Eight isonitrogenous ( $46 \%$ crude protein) and isoenergetic $\left(3,450 \mathrm{kcal} \mathrm{kg}^{-1}\right.$ digestible energy) diets, with increasing levels of CGM - 0, 6, 12, 18, 24, $30,36$, and $42 \%$-, were fed to juvenile striped catfish (113.56 $\pm 5.10 \mathrm{~g})$ for seven weeks. Maximum values for weight gain, specific growth rate, protein efficiency ratio and feed conversion ratio, evaluated by polynomial quadratic regression, were observed with $10.4,11.4,15.4$ and $15 \%$ of CGM inclusion, respectively. Feed intake decreased significantly from $0.8 \%$ CGM. Mesenteric fat index and body gross energy decreased linearly with increasing levels of CGM; minimum body protein contents were observed with $34.1 \%$ CGM. Yellow pigmentation of fillets significantly increased until 26.5\% CGM, and decreased from this point forth. Both plasma glucose and protein concentrations decreased with increased CGM levels. The inclusion of 10-15\% CGM promotes optimum of striped catfish juveniles depending on the parameter evaluated. Yellow coloration in fillets produced by CGM diets can have marketing implications.

Index terms: alternative protein source, carnivorous fish, fish nutrition, neotropical species, plant protein sources, striped catfish.

\section{Desempenho de juvenis de Pseudoplatystoma fasciatum alimentados com níveis crescentes de farelo de glúten de milho}

\begin{abstract}
Resumo - O objetivo deste trabalho foi avaliar o farelo de glúten de milho (FGM) como substituto à farinha de peixe, em dietas para juvenis de cachara (Pseudoplatystoma fasciatum). Oito dietas isonitrogenadas ( $46 \%$ de proteína bruta) e isoenergéticas ( $3.450 \mathrm{kcal} \mathrm{kg}^{-1}$ de energia digestível), com níveis crescentes de FGM - 0, 6, 12 , $18,24,30,36$ e $42 \%$-, foram fornecidas a juvenis de cachara $(113,56 \pm 5,10 \mathrm{~g})$ durante sete semanas. Valores máximos de ganho de peso, taxa de crescimento específico, taxa de eficiência proteica e índice de conversão alimentar, avaliados por regressão polinomial quadrática, foram observados com inclusão de 10,4, 11,4, 15,4 e $15 \%$ de FGM, respectivamente. A ingestão de alimento diminuiu significativamente a partir de $0,8 \%$ de FGM. $\mathrm{O}$ índice de gordura visceral e a energia bruta corporal diminuíram linearmente com aumento nos níveis de FGM; o teor mínimo de proteína bruta corporal foi observado com 34,1\% de FGM. A pigmentação amarelada dos filés aumentou significativamente até $26,5 \%$ de FGM, e diminuiu a partir daí. Tanto a glicose quanto a proteína plasmática diminuíram com o aumento em FGM. A inclusão de 10-15\% FGM proporciona ótimo desempenho produtivo de juvenis de cachara, dependendo do parâmetro avaliado. A coloração amarelada nos filés, produzida pela inclusão de FGM nas dietas, pode ter implicações comerciais.
\end{abstract}

Termos para indexação: fontes proteicas alternativas, peixes carnívoros, nutrição de peixes, espécie neotropical, fontes proteicas vegetais, cachara.

\section{Introduction}

The striped catfish Pseudoplatystoma fasciatum (Linnaeus 1766), a carnivorous, neotropical siluriform fish, is one of the most appreciated Brazilian freshwater fish, both as food and sport fish. Despite the information scarcity on its nutritional requirements, the use of the species in intensive farming systems

Pesq. agropec. bras., Brasília, v.47, n.6, p.838-845, jun. 2012 
grows steadily. Commercial feeds, diet formulations, and feeding practices for the species are based mainly on information for exotic fish (Campos, 2005).

Fish meal (FM), in spite of being the main dietary protein source for aquafeeds, especially for carnivorous fish, it is the most expensive diet component. Therefore, the search for alternative, surrogate protein sources for aquafeed production is a common trend in fish nutrition research.

Corn gluten meal (CGM) is a major corn wet milling by-product, bearing high-protein contents (minimum $60 \%$ ), high digestibility ( $>90 \%$ ) and high contents of methionine, leucine and glutamic acid (National Research Council, 2011), but it is deficient in lysine, arginine, and tryptophan (Mente et al., 2003). It also has strong undesirable odors and flavors because of its high content of unsaturated fatty acids and the bisulfite used during steeping (Park et al., 1997; Cha et al., 2000). Moreover, corn gluten meal is a rich source of carotenoids, mostly xanthophylls. Usually, commercial CGM contains from 224 to $550 \mathrm{mg} \mathrm{kg}^{-1}$ of xanthophyll on a dry matter basis (Park et al., 1997; Cha et al., 2000). Fish fed diets with high levels of CGM can show yellow-pinkish pigment deposits in the flesh (Robaina et al., 1997). In salmonids, the typical red-to-pink muscle color is an important trait. However, the yellow pigmentation of fillets of white-fleshed fishes reduces their market value (Lovell, 1984), a serious limitation to the use of CGM in neotropical fish diets.

Because CGM has a low-fiber content and no anti-nutritional factors, it could be considered as a good fish meal alternative ingredient, and its use as dietary protein source has been investigated for some freshwater and marine, cold water or subtropical fishes (Robaina et al., 1997; Regost et al., 1999; Mente et al., 2003; Pereira \& Oliva-Teles, 2003; Gómez-Requeni et al., 2004; Zhong et al., 2011). However, data on the use of corn gluten meal as a dietary protein source for neotropical species is scarce.

The objective of this work was to evaluate corn gluten meal (CGM) as a substitute for fish meal in diets for striped catfish juveniles.

\section{Materials and Methods}

Groups of eight juvenile striped catfish $(113.56 \pm 5.10 \mathrm{~g})$ were randomly stocked into 32 cages $(180 \mathrm{~L})$ installed in two $12-\mathrm{m}^{3}$ concrete tanks, in greenhouse conditions, with closed loop circulation system, continuous aeration (dissolved oxygen $4.62 \pm 0.58 \mathrm{mg} \mathrm{L}^{-1}$ ), and temperature control $\left(28.02 \pm 1.31^{\circ} \mathrm{C}\right)$. It was used a completely randomized block design, with four repetitions.

Fish were fed to apparent satiation twice a day (at $8 \mathrm{~h}$ and $16 \mathrm{~h}$ ), for seven weeks, with eight isonitrogenous ( $46 \%$ crude protein) and isoenergetic $\left(3,450 \mathrm{kcal} \mathrm{kg}^{-1}\right.$ digestible energy) diets (Table 1), containing increasing levels of CGM - 0, 6, 12, 18, 24, 30,36 and $42 \%$ - replacing the protein from fish meal in $0.0,12.5,25.0,37.5,50.0,62.5,75.0$, and $87.5 \%$, respectively. Digestible energy concentrations of feed ingredients were calculated from data by Gonçalves \& Carneiro (2003) for speckled catfish Pseudoplatystoma corruscans, and by Portz \& Cyrino (2004) for largemouth bass Micropterus salmoides. Corn was not used for formulation of diets to guarantee CGM to be the only source of carotenoids $\left(0.239 \mathrm{mg} \mathrm{g}^{-1}\right.$ of xanthophyll). For diet processing, feedstuffs were ground, homogenized ( $1 \mathrm{~mm}$ sieve), mixed, moistened and granulated in an industrial mincer. Pellets were dried in a forced-air oven (at $45^{\circ} \mathrm{C}$ for 18 hours), crumbled, sized $(4 \mathrm{~mm})$, hermetically packed and stored under refrigeration until use.

Growth and feed utilization performances were determined based on the following parameters: final body weight $(\mathrm{g})$; weight gain $(\%)=[$ (weight gain $/$ initial body weight $) \times 100$ ]; specific growth rate $(\%$ per day $)=\{[(\ln$ mean final weight $-\ln$ mean initial weight)/total experimental feeding in days $] \times 100\}$; feed conversion ratio $=$ total feed fed/total weight gain; daily feed intake $=$ total feed fed/total experimental feeding days; protein efficiency ratio $=$ weight gain of fish/total protein allowed; condition factor $=\{$ [live weight $\left.\left./(\text { total length })^{3}\right] \times 100\right\}$; pigment intake $=$ feed intake $\times$ pigment concentration in CGM $\left(0.239 \mathrm{mg} \mathrm{g}^{-1}\right.$ of xanthophyll); hepatosomatic index $=[$ (liver weight $/$ body weight $) \times 100]$; viscerosomatic index $=[($ visceral weight/body weight $) \times 100$ ]; and mesenteric fat index $=$ $[($ mesenteric fat weight/body weight $) \times 100]$.

A pooled sample of 10 fish from the original population was euthanized by anesthetic overdoses (500 $\mathrm{mg} \mathrm{L}^{-1}$ benzocaine) for the determination of whole-body composition. At the end of the growth trial, two fish per cage were randomly sampled and euthanized as previously described. Specimens for 
body analysis were ground and frozen to estimate water content, gross energy and crude protein.

Duplicate colorimetric measurements were made in three different points of skinless fillets stored on ice $\left(3-4^{\circ} \mathrm{C}\right)(\mathrm{n}=6)$. Data were expressed using the $\mathrm{L}^{*} \mathrm{a}^{*} \mathrm{~b}$ system, representing lightness, redness and yellowness, according to Commission Internationale de L'Éclairage (1976).

Blood samples were randomly drawn from the caudal vein of six fish per treatment, using $3 \mathrm{~mL}$ plastic syringes rinsed with EDTA $10 \%$ in $0.6 \%$ saline solution. Fish fasted for 16 hours and were anesthetized prior to sampling. Plasma was collected after centrifugation at 5,000 rpm for $5 \mathrm{~min}$, and frozen stored $\left(-20^{\circ} \mathrm{C}\right)$ until biochemical analysis. Samples were thawed immediately prior to analyses which were made within seven days after collection. Total plasma protein concentration $\left(\mathrm{g} \mathrm{dL}^{-1}\right)$ was determined with a clinical refractometer, and plasma glucose $\left(\mathrm{mg} \mathrm{dL}^{-1}\right)$ was determined with an oxidase/peroxidase reaction colorimetric test (Laborlab, Guarulhos, SP, Brazil). Chemical analyses of the diets and of fish body samples were carried out according to Horwitz (2000). Gross energy was determined using an adiabatic calorimetric bomb with benzoic acid as the standard.
Significant effects of dietary CGM levels were determined by one-way ANOVA, at 5\% probability. A polynomial regression analysis was used to study performance, nutrient retention, body composition, fillet quality, morphological and biochemical parameters. Pearson correlation coefficients were calculated to measure the strength of linear association between different variables. Data were analyzed with SAS program version 9.1.3 (SAS Institute, 2003).

\section{Results and Discussion}

Optimum weight gain was registered for fish fed $10.4 \%$ CGM diet, and decreased steadily with increasing dietary CGM (Figure 1). The optimum inclusion of CGM that resulted maximum specific growth rate was $11.4 \%$ CGM. Conversely, specific growth rate of fish fed $42 \%$ CGM was $70 \%$ lower than that of fish fed control diet. Protein efficiency ratio peaked at $15.4 \%$ dietary CGM. Feed conversion ratio decreased when dietary CGM was higher than $15 \%$, although the smallest value (1.9) can still be considered within an adequate range for farmed carnivorous fish.

These results are lower than those reported for other species. Replacing up to one third of dietary FM by CGM's protein did not affect the performance of turbot Psetta maxima fingerlings (Regost et al., 1999);

Table 1. Ingredients and proximate composition of experimental diets with increasing levels of corn gluten meal for juvenile striped catfish (Pseudoplatystoma fasciatum).

\begin{tabular}{|c|c|c|c|c|c|c|c|c|}
\hline \multirow[t]{2}{*}{ Ingredient (\%) } & \multicolumn{8}{|c|}{ Corn gluten meal inclusion level (\%) } \\
\hline & 0 & 6 & 12 & 18 & 24 & 30 & 36 & 42 \\
\hline Corn gluten meal & 0.00 & 6.00 & 12.00 & 18.00 & 24.00 & 30.00 & 36.00 & 42.00 \\
\hline Fish meal & 48.21 & 42.00 & 36.00 & 30.00 & 24.00 & 18.00 & 12.00 & 6.00 \\
\hline Soybean meal & 24.98 & 22.93 & 20.63 & 18.32 & 16.00 & 13.63 & 11.26 & 8.88 \\
\hline Poultry by-products meal & 10.00 & 10.00 & 10.00 & 10.00 & 10.00 & 10.00 & 10.00 & 10.00 \\
\hline Wheat flour & 1.81 & 5.67 & 9.58 & 13.50 & 17.47 & 21.63 & 25.78 & 29.93 \\
\hline Fish oil & 7.00 & 7.00 & 7.00 & 7.00 & 6.53 & 4.75 & 2.97 & 1.19 \\
\hline Soybean oil & 6.00 & 4.40 & 2.79 & 1.18 & 0.00 & 0.00 & 0.00 & 0.00 \\
\hline$\underline{\text { Mineral and vitamin premix }}^{(1)}$ & 2.00 & 2.00 & 2.00 & 2.00 & 2.00 & 2.00 & 2.00 & 2.00 \\
\hline \multicolumn{9}{|l|}{ Proximate analyses (wet weight) } \\
\hline Crude protein $(\%)$ & 46.09 & 45.78 & 45.29 & 45.84 & 45.43 & 46.51 & 46.56 & 45.82 \\
\hline Dry matter (\%) & 97.77 & 95.07 & 86.87 & 97.42 & 97.22 & 96.75 & 96.91 & 96.82 \\
\hline Crude ash $(\%)$ & 16.13 & 15.22 & 12.70 & 11.76 & 11.01 & 7.96 & 7.02 & 6.14 \\
\hline Gross energy $\left(\mathrm{kcal} \mathrm{kg}^{-1}\right)$ & 5,134 & 5,121 & 5,056 & 5,052 & 5,033 & 4,931 & 4,900 & 4,822 \\
\hline Digestible energy $\left(\mathrm{kcal} \mathrm{kg}^{-1}\right)^{(2)}$ & 3,450 & 3,450 & 3,450 & 3,450 & 3,450 & 3,450 & 3,450 & 3,450 \\
\hline Lysine $(\%)^{(3)}$ & 2.68 & 2.48 & 2.28 & 2.09 & 1.89 & 1.69 & 1.49 & 1.30 \\
\hline
\end{tabular}

Pesq. agropec. bras., Brasília, v.47, n.6, p.838-845, jun. 2012 
the same was observed for Atlantic salmon Salmo salar fed diets, with CGM replacing $25 \%$ of FM protein (Mente et al., 2003), and for gilthead sea bream Sparus aurata fed diets with CGM replacing $60 \%$ of FM protein (Pereira \& Oliva-Teles, 2003) or $30 \%$ of the total dietary protein (Robaina et al., 1997).
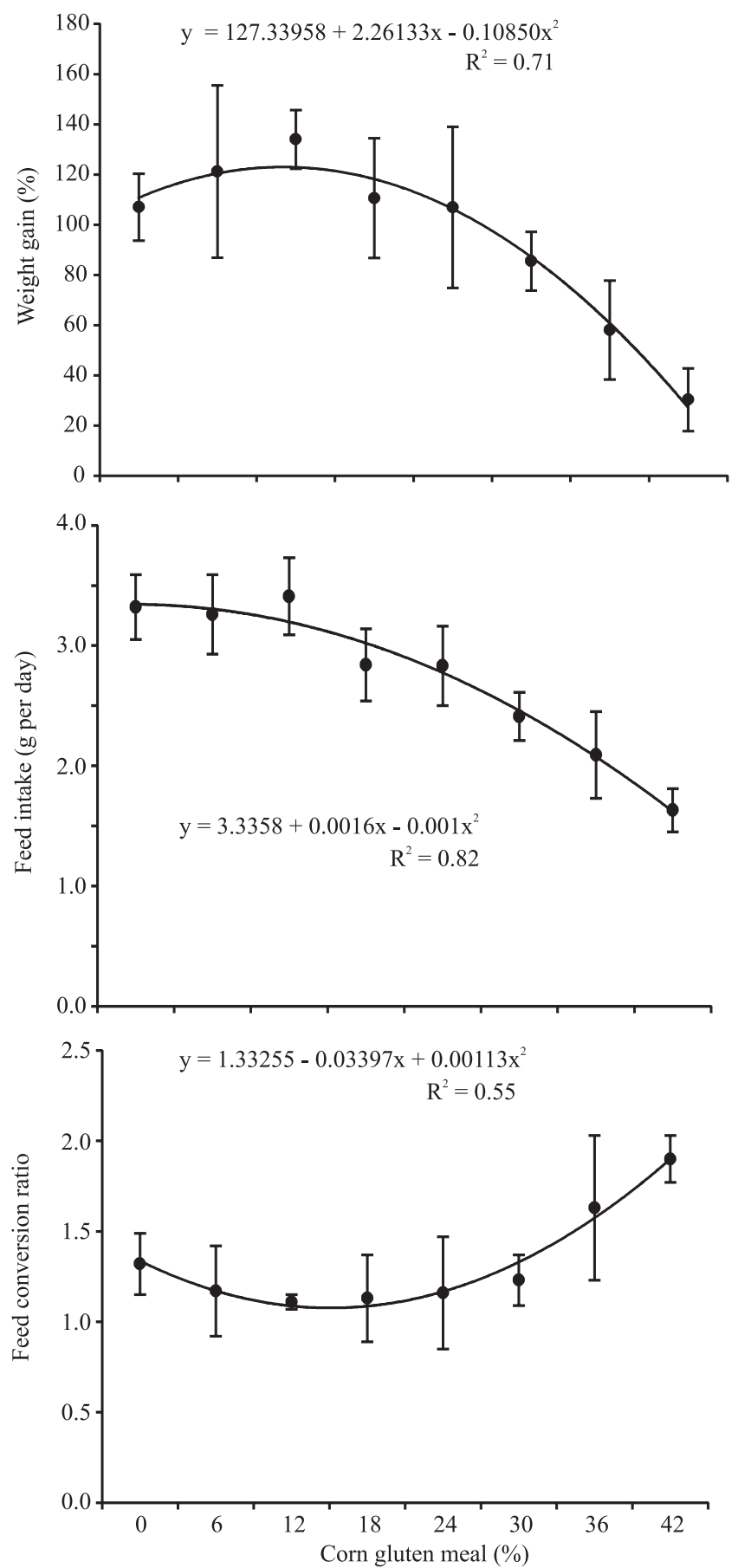

However, Ballestrazzi et al. (1994) reported a reduced performance of sea bass Dicentrarchus labrax fed diets containing more than 20\% CGM. The difference in upper limit of CGM proportion among different studies might be related to the different fish species and different developmental stages used in these studies.
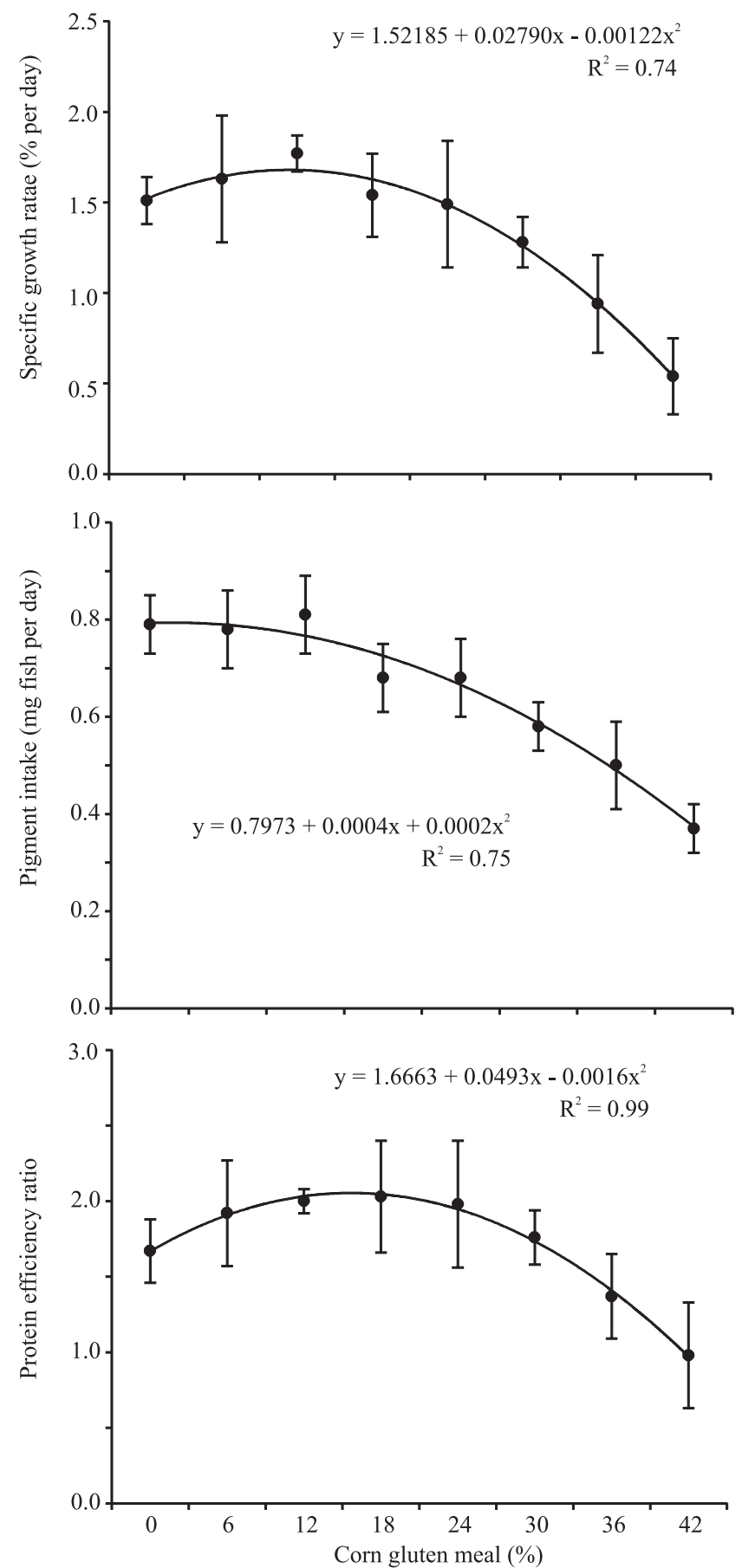

Figure 1. Growth and feed utilization of juvenile striped catfish (Pseudoplatystoma fasciatum) fed diets with increasing levels of corn gluten meal. 
Decrease $(\mathrm{p}<0.05)$ in the growth rate and feed efficiency can be attributed to decreased dietary lysine, CGM's most limiting amino acid, whose dietary deficiency severely affects fish growth (Wilson, 2003). Although dietary lysine requirements of striped catfish are still to be defined, it can be inferred from the results of the current study that it is close to $2.28 \%$ (5\% of dietary protein). Similar requirement values were reported for other carnivorous species (Wilson, 2003).

Plant protein ingredients may show anti-nutritional factors (e.g., protease inhibitors), which negatively affect fish performance. Based on in vitro assays, Moyano López et al. (1999) concluded that inhibition of protease activity in $S$. aurata was positively correlated with dietary CGM levels, even though CGM protein is considered of high biological value (Robaina et al., 1997; Pereira \& Oliva-Teles, 2003; National Research Council, 2011). Zhong et al. (2011) found that trypsin activity is regulated by the amount of CGM used as a partial replacement for conventional fish meal, and observed that the trypsin activity decreased significantly at a concentration of $20 \%$ CGM in the diets for Fugu obscurus. The authors hypothesize that the amino acid composition of the diet changes the substrate specificity of trypsin, even though protein content is unchanged. For example, when the alternative sites in a substrate are hydrolyzed by the enzyme, the feedback mechanism may signal the synthesis of the endogenous enzyme ultimately leading to decreased synthesis of trypsinogen and trypsin activity. That could explain, in part, why striped catfish fed diets with the highest levels of dietary CGM showed the worst performance and feed efficiency indexes.

The reduction herein registered in the growth parameters cannot be explained as a result of varying dietary CGM levels alone. Increasing plant protein sources and reducing fish meal increase dietary carbohydrate levels. According to Hemre et al. (2002), carbohydrate levels in fish diets are sort out as tolerable or optimal, a tolerable level being one that does not impair growth or result in increased mortality, whereas optimum levels are defined as those resulting in full oxidation of glucose to produce energy, therefore sparing protein. Carnivorous fish utilize dietary carbohydrate poorly, and usually levels up to $10 \%$ decrease their growth performance (Wilson, 1994). However, Takahashi \& Cyrino (2006) did not report reduction on performance of speckled catfish $P$. corruscans fed granulated diets until 29\% of nonstructural carbohydrates.

The feed intake of fish fed 42\% CGM (1.63 g per day) was $51 \%$ lower than that of fish fed control diet (3.32 g per day). Reduction ( $\mathrm{p}<0.05)$ on feed intake was observed from $0.8 \%$ CGM (Figure 1), although, at this level, it was not observed a significant decrease on weight gain and feed conversion ratio. The proportional reduction in feed intake in response to increasing dietary CGM was expected to some extent, and it had been already reported in other studies (Pereira \& Oliva-Teles, 2003; Gómez-Requeni et al., 2004). CGM is considered a somewhat unpalatable feedstuff as a result of its processing (Park et al., 1997; Cha et al., 2000). Adequate amino acid profiles positively affect food consumption of fish, since some amino acids can work as attractants (Wilson, 2003). So, low-feed intake and overall lower performance of fish fed diets with the highest levels of CGM can be credited to CGM's inadequate amino acid profile.

The body composition of fish was affected by diet composition (Table 2). Increasing dietary CGM resulted in decreased gross energy $(\mathrm{y}=5.6175-0.0107 \mathrm{x}$, $\left.\mathrm{R}^{2}=0.41\right)$ and mesenteric fat index $(\mathrm{y}=1.42-0.0135 \mathrm{x}$, $\left.\mathrm{R}^{2}=0.58\right)$ and, as a consequence, significant increase in body moisture $\left(\mathrm{y}=68.257+0.1723 \mathrm{x}, \mathrm{R}^{2}=0.62\right)$. In addition, condition factor also decrease $\left(\mathrm{y}=1.13375-0.00599 \mathrm{x}, \mathrm{R}^{2}=0.50\right)$ with increasing CGM level. An inverse relationship between body moisture and body lipid was reported for other Brazilian fish (Bicudo et al., 2010). Minimum body protein contents were observed in fish fed diets containing 34.1\% CGM $\left(y=18.968-0.1569 x+0.0023 x^{2}, R^{2}=0.67\right)$, and from this point, body-protein content was virtually stable. The hepatosomatic index varied from 1.37 to $2.56 \%$, with maximum value recorded for $29.7 \%$ CGM inclusion $\left(\mathrm{y}=2.432-0.128 \mathrm{x}+0.0088 \mathrm{x}^{2}+0.0001 \mathrm{x}^{3}\right.$, $\left.\mathrm{R}^{2}=0.57\right)$. The hepatosomatic index of fish fed the control diet was $72 \%$ higher than that of fish fed diet containing 42\% CGM. Dietary CGM levels did not affect $(\mathrm{p}>0.05)$ viscerosomatic index, lightness and $\mathrm{pH}$ of fillets.

Reports on effects of dietary plant protein on body composition of carnivorous fish are controversial. Growth encompasses neoplasia, hyperplasia, and the storage and mobilisation of energy reserves; all of these bodily phenomena may involve changes in body 
composition, including large net losses (Jobling, 2002). In the present study, total body protein of striped catfish was influenced by dietary formulation. Probably, decrease in body protein is associated with decreasing dietary lysine, since the influence of this amino acid in protein synthesis is well established (Wilson, 2003; Bicudo et al., 2009). However, Regost et al. (1999) and Pereira \& Oliva-Teles (2003) did not report any effect of CGM on whole body-protein contents of turbot and gilthead sea bream, respectively.

Yellow coloration (yellowness - b) of fillets increased with increasing dietary CGM content until $26.5 \%$ inclusion level, and decreased from this point forth. Although xanthophylls concentration increased linearly with increasing dietary CGM, the yellow coloration of juvenile striped catfish muscle showed a quadratic effect of distribution $\left(\mathrm{y}=11.009+0.3644 \mathrm{x}-0.0069 \mathrm{x}^{2}, \mathrm{R}^{2}=0.91\right)$. It may have happened because of the decreased feed intake with increasing CGM inclusion levels. This hypothesis would appear to be corroborated by daily pigment intake, that decreased from $0.8 \%$ CGM (Figure 1), showing a similar trend of feed intake. In gilthead sea bream, Robaina et al. (1997) observed a linear relationship between yellow coloration of muscle and dietary CGM. A concentration of $0.6 \mathrm{~g}$ carotenoid per gram of flesh produces a distinguishable yellow coloration of the fillet; a discernible concentration of carotenoid can be deposited in the fillets of channel catfish Ictalurus punctatus fed diets containing $11 \mathrm{mg} \mathrm{kg}^{-1}$ xanthophyll
(National Research Council, 2011). As a matter of fact, this concentration ( $\left.11 \mathrm{mg} \mathrm{kg}^{-1}\right)$ is easily achieved with $5-10 \%$ of CGM in fish diets (Li et al., 2007). Therefore, inclusion levels ranging from 10.4-15.4\% CGM, which provided best growth performance in the present study, probably will negatively affect the coloration of fillets of striped catfish. Further studies are needed to develop strategies to reduce the yellow pigmentation in the fillet of striped catfish fed high levels of corn gluten meal.

Total plasma protein and plasma glucose were reduced $(p<0.05)$ with increasing replacement of FM by CGM (Figure 2), both showing a quadratic distribution effect. A linear negative correlation was identified between plasma glucose $(\mathrm{r}=-0.797 ; \mathrm{p}<0.0001)$ and total protein $(r=-0.880 ; p<0.0001)$ responses to dietary CGM levels. Fish fed diets with the highest CGM level $(42 \%)$ had a $47.3 \%$ reduction of plasma glucose (from 123.90 to $65.29 \mathrm{mg} \mathrm{dL}^{-1}$ ) and $65.2 \%$ of plasma protein (from 16.65 to $5.80 \mathrm{~g} \mathrm{dL}^{-1}$ ) in comparison to fish fed control diet.

The increasing of protein to carbohydrate ratio in diets of speckled catfish reduced the glycemia (Lundsted et al., 2004). Reduction in plasma glucose levels were registered by Gómez-Requeni et al. (2004) in gilthead sea bream, when $75 \%$ of dietary fish meal was replaced by plant protein. However, Sitjà-Bobadilla et al. (2005) did not report significant changes in plasma glucose, when dietary fish meal was replaced by up to $100 \%$ plant protein sources for the same species.

Table 2. Body composition, fillet quality and morphological parameters of juvenile striped catfish (Pseudoplatystoma fasciatum) fed diets with increasing levels of corn gluten meal ${ }^{(1)}$.

\begin{tabular}{lcccccccc}
\hline Parameter & \multicolumn{7}{c}{ Corn gluten meal inclusion level (\%) } \\
\cline { 2 - 8 } & 0 & 6 & 12 & 18 & 24 & 30 & 36 \\
\hline & & & \multicolumn{7}{c}{ Final body composition } \\
Moisture (\%) & $66.3 \pm 2.6$ & $68.4 \pm 0.5$ & $71.3 \pm 1.1$ & $71.8 \pm 1.0$ & $71.9 \pm 0.1$ & $73.0 \pm 0.5$ & $75.0 \pm 2.1$ & $73.7 \pm 2.5$ \\
Protein (\%) & $18.8 \pm 0.9$ & $18.8 \pm 1.0$ & $17.4 \pm 0.1$ & $17.0 \pm 0.2$ & $16.2 \pm 0.6$ & $16.6 \pm 0.5$ & $16.2 \pm 0.7$ & $16.5 \pm 0.5$ \\
Gross energy (kcal kg-1) & $5.59 \pm 0.08$ & $5.53 \pm 0.04$ & $5.56 \pm 0.03$ & $5.35 \pm 0.02$ & $5.68 \pm 0.03$ & $4.93 \pm 0.04$ & $5.28 \pm 0.03$ & $5.22 \pm 0.02$ \\
\hline & & \multicolumn{5}{c}{ Morphological parameters } \\
Hepatosomatic index (\%) & $2.36 \pm 0.42$ & $1.98 \pm 0.27$ & $2.21 \pm 0.25$ & $1.92 \pm 0.29$ & $2.05 \pm 1.04$ & $2.56 \pm 0.82$ & $2.56 \pm 0.48$ & $1.37 \pm 0.93$ \\
Mesenteric fat index (\%) & $1.57 \pm 0.4$ & $1.22 \pm 0.2$ & $1.24 \pm 0.4$ & $1.02 \pm 0.2$ & $1.09 \pm 0.4$ & $1.13 \pm 0.7$ & $1.21 \pm 0.7$ & $0.64 \pm 0.6$ \\
Viscerosomatic index (\%) & $5.03 \pm 0.6$ & $4.49 \pm 1.0$ & $4.70 \pm 0.9$ & $4.93 \pm 0.6$ & $4.43 \pm 0.7$ & $4.84 \pm 1.5$ & $4.99 \pm 0.7$ & $4.70 \pm 0.6$ \\
Condition factor & $1.15 \pm 0.1$ & $1.08 \pm 0.1$ & $1.10 \pm 0.1$ & $0.97 \pm 0.1$ & $1.00 \pm 0.1$ & $0.91 \pm 0.2$ & $0.91 \pm 0.1$ & $0.89 \pm 0.1$ \\
\hline & & & \multicolumn{5}{c}{} \\
pH & $6.1 \pm 0.2$ & $6.3 \pm 0.2$ & $6.1 \pm 0.2$ & $6.1 \pm 0.1$ & $6.2 \pm 0.2$ & $6.1 \pm 0.1$ & $6.0 \pm 0.1$ & $6.1 \pm 0.2$ \\
L (lightness) & $57.8 \pm 2.1$ & $57.8 \pm 2.5$ & $54.6 \pm 1.5$ & $54.3 \pm 2.2$ & $56.3 \pm 2.3$ & $57.6 \pm 2.4$ & $55.8 \pm 1.1$ & $56.2 \pm 3.4$ \\
b (yellowness) & $11.4 \pm 1.5$ & $12.7 \pm 1.3$ & $14.4 \pm 1.1$ & $14.6 \pm 1.2$ & $15.8 \pm 1.9$ & $16.7 \pm 1.8$ & $15.6 \pm 1.7$ & $13.6 \pm 2.3$ \\
\hline
\end{tabular}

${ }^{(1)}$ Means \pm standard deviation $(\mathrm{n}=4)$. 
The onset of the physiological condition of starvation is rapidly characterized by an almost immediate and substantial decrease in concentrations of soluble protein and glucose in the plasma (Viana et al., 2007). Considering that the digestion of carbohydrates is usually disregarded in carnivorous fish, significant linear reduction in plasma glucose were registered in species fed diets containing excess of $10 \%$ of starch (Hemre et al., 2002). However, the slower reduction of plasma glucose in the highest replacement levels indicates that the striped catfish maintain their glucose homeostasis through gluconeogenic metabolism. Sitjà-Bobadilla et al. (2005) registered a $20 \%$ reduction in plasma protein of juvenile gilthead sea bream, when $100 \%$ of dietary FM was replaced by plant protein.
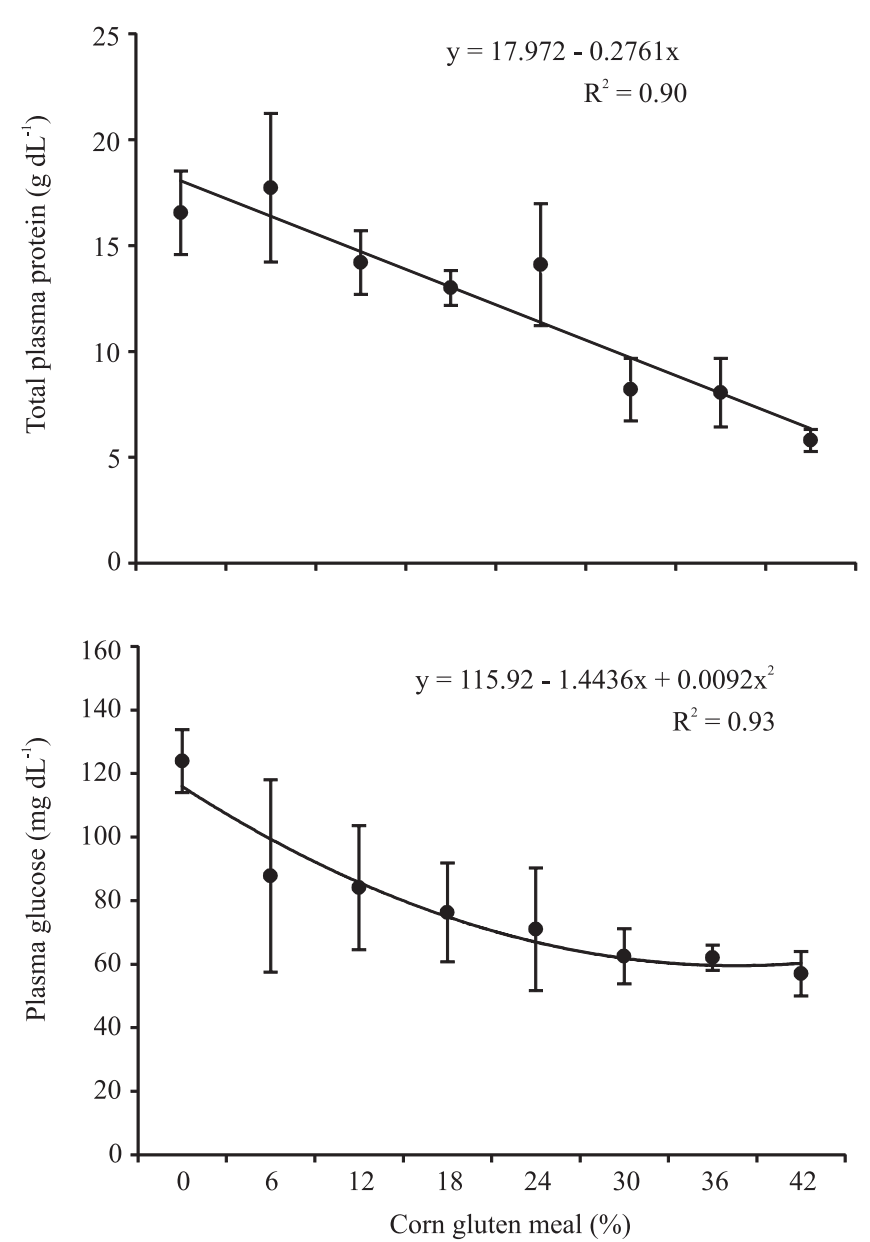

Figure 2. Relationship between levels of corn gluten meal (CGM) inclusion in the diet and total plasma protein and plasma glucose of juveniles striped catfish (Pseudoplatystoma fasciatum).

\section{Conclusion}

Corn gluten meal can partially replace fish meal in diets of juvenile striped catfish diets without affecting growth performance; however, it causes yellow pigmentation of fillets that is an undesirable characteristic for its commercialization.

\section{Acknowledgements}

To Fundação de Amparo à Pesquisa do Estado de São Paulo, and to Conselho Nacional de Desenvolvimento Científico e Tecnológico, for scholarships.

\section{References}

BALLESTRAZZI, R.; LANARI, D.; D'AGARO, E.; MION, A. The effect of dietary protein level and source on growth, body composition, total ammonia and reactive phosphate excretion of growing sea bass (Dicentrarchus labrax). Aquaculture, v.127, p.197-206, 1994.

BICUDO, A.J.A.; SADO, R.Y.; CYRINO, J.E.P. Dietary lysine requirement of juvenile pacu Piaractus mesopotamicus (Holmberg, 1887). Aquaculture, v.297, p.151-156, 2009.

BICUDO, A.J.A.; SADO, R.Y.; CYRINO, J.E.P. Growth performance and body composition of pacu Piaractus mesopotamicus (Holmberg 1887) in response to dietary protein and energy levels. Aquaculture Nutrition, v.16, p.213-222, 2010.

CAMPOS, J.L. O cultivo do pintado, Pseudoplatystoma corruscans (Spix e Agassiz, 1829). In: BALDISSEROTTO, B.; GOMES, L.C. (Ed.). Espécies nativas para piscicultura no Brasil. Santa Maria: UFSM, 2005. p.327-343.

CHA, J.Y.; FLORES, R.A.; PARK, H. Reduction of carotenoids in corn gluten meal with soy flour. Transactions of the ASAE, v.43, p.1169-1174, 2000.

COMMISSION INTERNATIONALE DE L'ÉCLAIRAGE. Colorimetry. Vienna: Bureau Central de la CIE, 1976.

GÓMEZ-REQUENI, P.; MINGARRO, M.; CALDUCH-GINER, J.A.; MÉDALE, F.; MARTIN, S.A.M.; HOULIHAN, D.F.; KAUSHIK, V; PÉREZ-SÁNCHEZ, J. Protein growth performance, amino acid utilisation and somatotropic axis responsiveness to fish meal replacement by plant protein sources in gilthead sea bream (Sparus aurata). Aquaculture, v.232, p.493-510, 2004.

GONÇALVES, E.G.; CARNEIRO, D.J. Coeficientes de digestibilidade aparente da proteína e energia de alguns ingredientes utilizados em dietas para o pintado (Pseudoplatystoma coruscans). Revista Brasileira de Zootecnia, v.32, p.779-786, 2003.

HEMRE, G.-I.; MOMMSEN, T.P.; KROGDAHL, Å. Carbohydrates in fish nutrition: effects on growth, glucose metabolism and hepatic enzymes. Aquaculture Nutrition, v.8, p.175-194, 2002.

HORWITZ, W. (Ed.). Official methods of analysis of AOAC International. $17^{\text {th }}$ ed. Gaithersburg: AOAC International, 2000. $1141 \mathrm{p}$. 
JOBLING, M. Nutrient partitioning and the influence of feed composition on body composition. In: HOULIHAN, D.; BOUJARD, T.; JOBLING, M. (Ed.). Food intake in fish. Oxford: Blackwell, 2002. p.354-375.

LI, M.H.; ROBINSON, E.H.; OBERLE, D.F. Effects of various dietary carotenoid pigments on fillet appearance and pigment absorption in channel catfish, Ictalurus punctatus. Journal of the World Aquaculture Society, v.38, p.557-563, 2007.

LOVELL, T. The yellow fat problem in fish flesh. Aquaculture Management, v.10, p.39-40, 1984.

LUNDSTED, L.M.; MELO, J.F.B.; MORAES, G. Digestive enzymes and metabolic profile of Pseudoplatystoma corruscans (Teleostei: Siluriformes) in response to diet composition. Comparative Biochemistry and Physiology - Part B: Biochemistry and Molecular Biology, v.137, p.331-339, 2004.

MENTE, E.; DEGUARA, S.; SANTOS, M.B.; HOULIHAN, D. White muscle free amino acid concentrations following feeding a maize gluten dietary protein in Atlantic salmon (Salmo salar L.). Aquaculture, v.225, p.133-147, 2003.

MOYANO LÓPEZ, F.J.; MARTÍNEZ DÍAZ, I.; DÍAZ LÓPEZ, M.; ALARCÓN LÓPEZ, F.J. Inhibition of digestive proteases by vegetable meals in three fish species; seabream (Sparus aurata), tilapia (Oreochromis niloticus) and African sole (Solea senegalensis). Comparative Biochemistry and Physiology Part B: Biochemistry and Molecular Biology, v.122, p.327-332, 1999.

NATIONAL RESEARCH COUNCIL. Nutrient requirements of fish and shrimp. Washington: National Academy Press, 2011. $376 \mathrm{p}$.

PARK, H.; FLORES, R.A.; JOHNSON, L.A. Preparation of fish feed ingredients: reduction of carotenoids in corn gluten meal. Journal of Agricultural and Food Chemistry, v.45, p.2088-2092, 1997.

PEREIRA, T.G.; OLIVA-TELES, A. Evaluation of corn gluten meal as a protein source in diets for gilthead sea bream (Sparus aurata L.) juveniles. Aquaculture Research, v.34, p.1111-1117, 2003.

PORTZ, L.; CYRINO, J.E.P. Digestibility of nutrients and amino acids of different protein sources in practical diets by largemouth bass Micropterus salmoides (Lacepéde, 1802). Aquaculture Research, v.35, p.312-320, 2004.

REGOST, C.; ARZEL, J.; KAUSHIK, S.J. Partial or total replacement of fish meal by corn gluten meal in diet for turbot (Psetta maxima). Aquaculture, v.180, p.99-117, 1999.

ROBAINA, L.; MOYANO, F.J.; IZQUIERDO, M.S.; SOCORRO, J.; VERGARA, J.M.; MONTERO, D. Corn gluten meal and bone meals as protein sources in diets for gilthead seabream (Sparus aurata): nutritional and histological implications. Aquaculture, v.157, p.347-359, 1997.

ROSTAGNO, H.S.; ALBINO, L.F.T.; DONZELE, J.L.; GOMES, P.C.; OLIVEIRA, R.F. de; LOPES, D.C.; FERREIRA, A.S.; BARRETO, S.L. de T. Tabelas brasileiras para aves e suínos: composição de alimentos e exigências nutricionais. 2.ed. Viçosa: UFV, 2005. 186p.

SAS INSTITUTE. SAS/STAT user's guide. Version 8.0. Cary: SAS Institute, 2003.

SITJÀ-BOBADILLA, A.; PEÑA-LLOPIS, S.; GÓMEZ-REQUENI, P.; MÉDALE, F.; KAUSHIK, S.; PÉREZ-SÁNCHEZ, J. Effect of fish meal replacement by plant protein sources on non-specific defense mechanisms and oxidative stress in gilthead sea bream (Sparus aurata). Aquaculture, v.249, p.387-400, 2005.

TAKAHASHI, L.S.; CYRINO, J.E.P. Dietary carbohydrate level on growth performance of speckled catfish, Pseudoplatystoma coruscans. Journal of Aquaculture in the Tropics, v.21, p.13-19, 2006.

VIANA, M.T.; D'ABRAMO, L.R.; GONZALEZ, M.A.; GARCÍA-SUÁREZ, J.V.; SHIMADA, A.; VÁSQUEZ-PELÁEZ, C. Energy and nutrient utilization of juvenile green abalone (Haliotis fulgens) during starvation. Aquaculture, v.264, p.323-329, 2007.

WILSON, R.P. Amino acid requirements of finfish and crustaceans. In: D'MELLO, J.P.F. (Ed.). Amino acids in animal nutrition. Cambridge: CABI Publishing, 2003. p.427-447.

WILSON, R.P. Utilization of dietary carbohydrate by fish. Aquaculture, v.124, p.67-80, 1994.

ZHONG, G.; QIAN, X.; HUA, X.; ZHOU, H. Effects of feeding with corn gluten meal on trypsin activity and mRNA expression in Fugu obscurus. Fish Physiology and Biochemistry, v.37, p.453-460, 2011.

$\overline{\text { Received on February 23, } 2011 \text { and accepted on May 15, } 2012}$ 